\title{
GARP: a surface molecule of regulatory $T$ cells that is involved in the regulatory function and TGF- $\beta$ releasing
}

\author{
Liping Sun ${ }^{1,3,4, *}$, Hao Jin ${ }^{1,3,4, *}$ and Hui Li ${ }^{2,3,4}$ \\ ${ }^{1}$ Department of Immunology, Tianjin Medical University Cancer Institute and Hospital, Tianjin, China \\ ${ }^{2}$ Department of Gastrointestinal Cancer Biology, Tianjin Medical University Cancer Institute and Hospital, Tianjin, China \\ ${ }^{3}$ Key Laboratory of Cancer Immunology and Biotherapy, Tianjin, China \\ ${ }^{4}$ National Clinical Research Center of Cancer, Tianjin, China \\ * These authors have contributed equally to this work \\ Correspondence to: Hui Li, email: lihvi@tjmuch.com \\ Keywords: regulatory T cells, glycoprotein A repetitions predominant, transforming growth factor $\beta$ \\ Received: January 24, $2016 \quad$ Accepted: April 04, $2016 \quad$ Published: April 15, 2016
}

\section{ABSTRACT}

There are many molecules that define regulatory $T$ cells (Tregs) phenotypically and functionally. Glycoprotein A repetitions predominant (GARP) is a transmembrane protein containing leucine rich repeats. Recently, GARP is found to express highly on the surface of activated Tregs. The combination of GARP and other surface molecules isolates Tregs with higher purity. Besides, GARP is a cell surface molecule of Tregs that maintains their regulatory function and homeosatsis. GARP has also been proved to promote the activation and secretion of transforming growth factor $\beta$ (TGF- $\beta$ ). Moreover, its potential value in cancer immunotherapy is also discussed in this work.

\section{INTRODUCTION}

$\mathrm{CD}^{+}$regulatory $\mathrm{T}$ cells (Tregs) are immunosuppressive $\mathrm{T}$ cells that play an important role in immune homeostasis. Because of difference in generation and mechanisms of action, there are two types of $\mathrm{CD}^{+}$ Tregs: naturally occurring Tregs (nTregs) and induced Tregs (iTregs) [1,2]. nTregs develop in thymus and migrate to peripheral tissues [1]. iTregs are derived from mature peripheral naive $\mathrm{CD}^{+} \mathrm{T}$ cells under a variety of conditions [3]. Although nTregs and iTregs differ in mechanisms of generation and functional properties, they share a similar phenotype [4].

A number of surface and intracellular molecules express highly in Tregs [1]. There are also some molecules that show low/negative expression on Tregs [5]. Because the use of them as reliable markers of Tregs is still limited, there are still many obstacles in therapeutic applications of Tregs. Glycoprotein A repetitions predominant (GARP) is a transmembrane protein consisting of 662 amino acids [6]. The expression of GARP is highly on the surface activated Tregs and increases the suppressive function of Tregs [7]. Additionally, GARP can bind to latent transforming growth factor $\beta$ (TGF- $\beta$ ), thus promoting secretion and activation of TGF- $\beta$ [8]. TGF- $\beta$ plays a critical rule for homeostasis and function of Tregs [9]. Finally, we discuss potential therapeutic value of GARP in cancer immunotherapy.

\section{TREG MARKERS}

To fully understand the role and function of Tregs, a number of surface and intracellular markers have been proved to be useful for identifying suppressive Tregs subsets, as summarized in Table 1. In 1970s, a subset of T cells with suppressive capacity was described firstly [10]. However, the lack of surface markers impedes the process of these cells. In 1995, Sakaguchi et al. first discovered that $\mathrm{CD}^{+} \mathrm{T}$ cells expressing $\mathrm{CD} 25$ were anergic and suppressive in mice [11]. Subsequently, CD25 is identified as a surface marker necessary for Tregs development and function $[12,13]$. However, only $1 \sim 2 \%$ of $\mathrm{CD}^{+} \mathrm{T}$ cells with highest $\mathrm{CD} 25$ expression are Tregs with suppressive function in human peripheral blood $[14,15]$. Thus, the use of CD25 as a surface marker of Tregs seems to be unconvinced, considering that human $\mathrm{CD} 4{ }^{+} \mathrm{CD} 25^{+} \mathrm{T}$ cells 
Table 1: Tregs markers

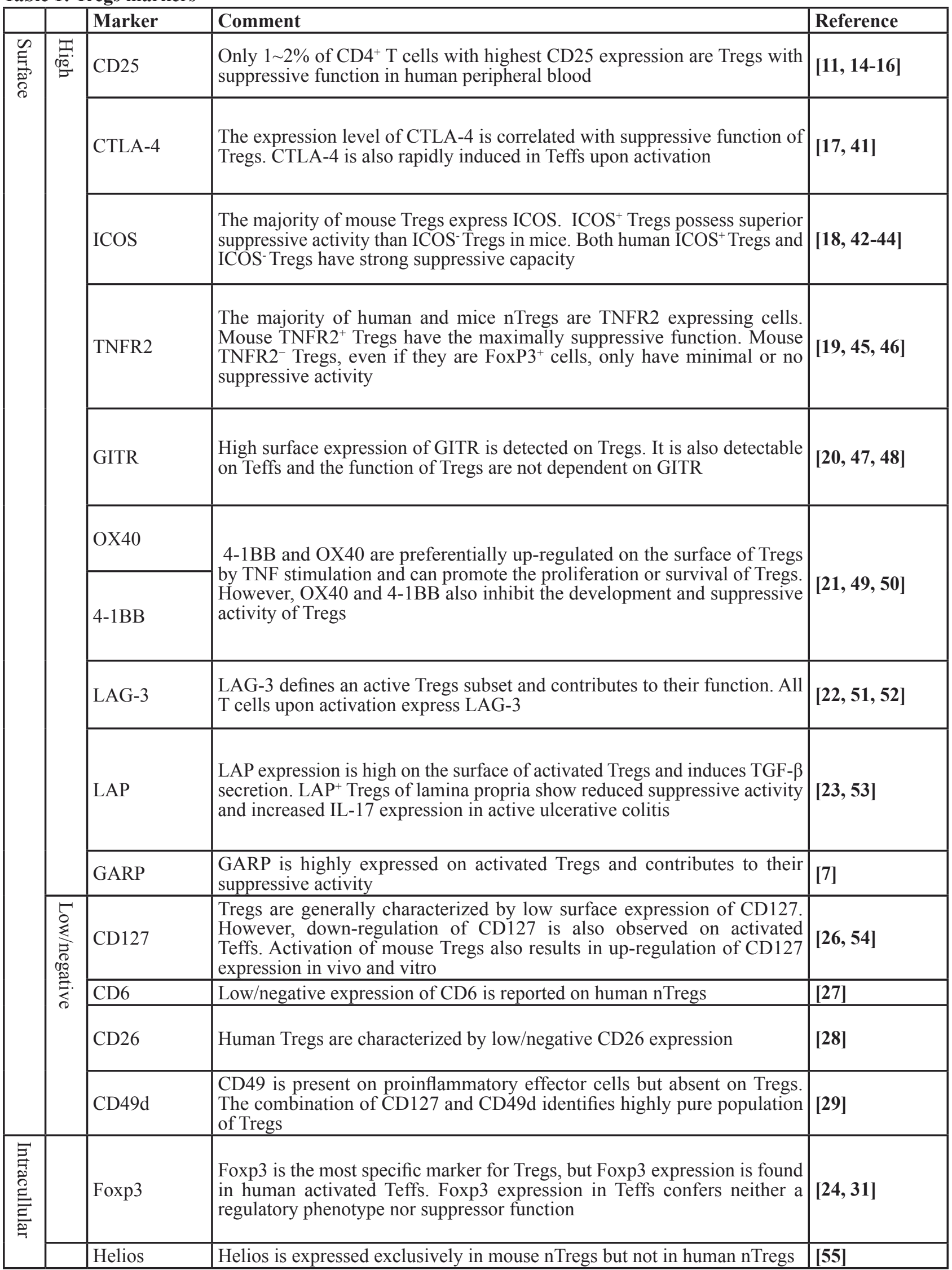


contain Tregs and activated Teffs [16]. Shortly thereafter, molecules like cytotoxic $\mathrm{T}$ lymphocyte-associated antigen 4 (CTLA-4) [17], inducible costimulator (ICOS) [18], tumor necrosis factor receptor 2 (TNFR2) [19], glucocorticoid-induced tumor necrosis factor receptor (GITR) [20], 4-1BB, OX40 [21], lymphocyte activation gene 3 (LAG-3) [22] and latency associated peptide (LAP) [23] are reported to express on the surface of Tregs. Intracellular molecules Foxp3 [24] and Helios [25] also express in Tregs strongly and constitutively. Additionally, several surface molecules like CD127 [26], CD6 [27], CD26 [28] and CD49d [29] show low/negative expression on Tregs.

The transcription factor Foxp3 is to date the most specific marker for Tregs. It is necessary for the development and function of Tregs [30]. However, Foxp3 expression is not specifically in human Tregs and is found in activated Teffs [31]. Foxp3 expression in Teffs confers neither a regulatory phenotype nor suppressor function [31-34]. Besides, Foxp3 cannot be used to separate functional Tregs for further researches because of its intracellular location [35]. In brief, the use of Foxp3 as a reliable marker for bona fide human Tregs is limited and not adequate to discriminate suppressive Tregs from other T cells.
In recent years, GARP is discovered to express highly on the surface of activated human Tregs in vitro [36]. Freshly isolated human Tregs and Tregs clones express a low level of surface GARP. With T cell receptor (TCR) stimulation, the surface expression of GARP on Tregs and Tregs clones is rapidly upregulated [9, 36]. Although GARP mRNA is detectable in human Th clones even its level close to some Treg clones, GARP is not detected on the surface of stimulated Th clones. The expression of GARP is very low $(\sim 3 \%)$ on the surface of activated Teffs $[9,37]$. In mice, GARP expression is also highly on the surface of activated Tregs [38]. Moreover, GARP expression is restricted to Foxp $3^{+}$population and more than $90 \%$ of the $\mathrm{CD}^{2} 5^{+} \mathrm{GARP}^{+} \mathrm{T}$ cells express Foxp3 [37]. Treg-specific demethylated region (TSDR) is an conserved non-coding region with $\mathrm{CpG}$ motifs in Foxp3 locus and unmethylated in Tregs to induce Foxp3 expression [39]. The portion of TSDR in $\mathrm{CD}^{+} \mathrm{GARP}^{+}$ $\mathrm{T}$ cells is $74 \%$, which is similar to the portion in $\mathrm{CD} 4^{+} \mathrm{CD} 25^{+} \mathrm{CD} 127^{\text {low }} \mathrm{T}$ cells $(74 \pm 4 \%)$ and higher than in $\mathrm{CD}^{+} \mathrm{CD} 25^{\mathrm{hi}} \mathrm{T}$ cells $(62 \pm 2 \%)$ [37]. A negligible expression $(5 \pm 1 \%)$ of CD154, an activation marker for Teffs, is observed on the surface of Tregs [40]. The combination of CD154 and GARP isolates Tregs with the highest suppressive activity [36]. Thus, GARP may serve

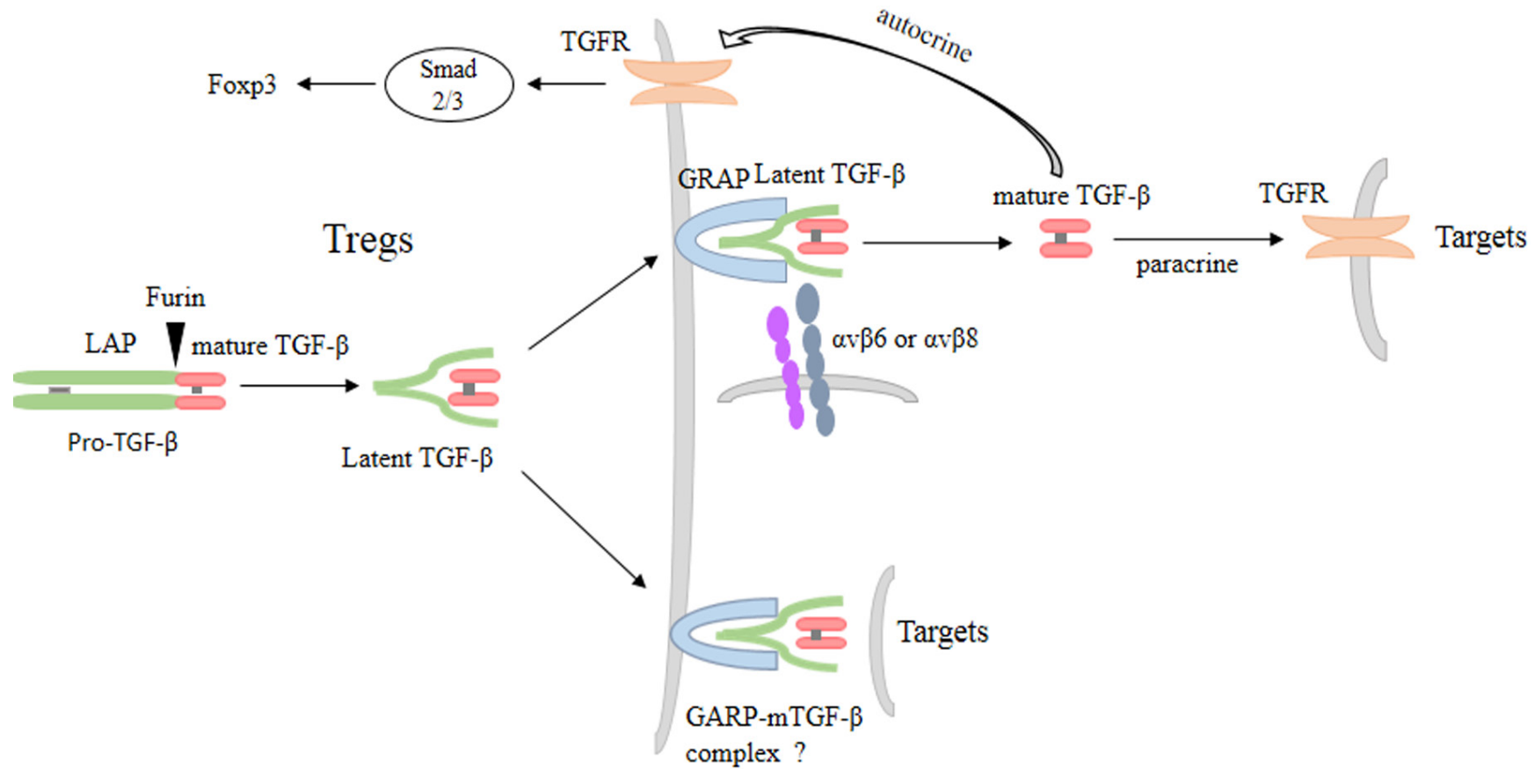

Figure 1: TGF- $\beta$ and GARP maintain homeostasis and function of Tregs. TGF- $\beta$ is synthesized as a pro-TGF- $\beta$ precursor, a homodimer that includes LAP and mature TGF- $\beta$. Then pro-TGF- $\beta$ are cleaved by the enzyme furin to form latent TGF- $\beta$, where mature TGF- $\beta$ remain noncovalently bind to the LAP. Membrane form of GARP transports and anchors latent TGF- $\beta$ to the surface of Tregs. The release of mature TGF- $\beta$ from the surface latent TGF- $\beta$ /GARP complex can be mediated by integrin. Mature TGF- $\beta$ in turn acts on Tregs themselves, forming a positive and autocrine TGF- $\beta$ feedback loop. Mature TGF- $\beta$ also acts on target cells in paracrine manner. Besides, the surface latent TGF- $\beta$ /GARP complex can also directly act on target cells and increases Tregs suppressive function, but the mechanism is still unclear. 
as an activated Tregs surface marker. The combination of GARP and other molecules can be used to separate functional Tregs.

\section{GARP GENE}

Human GARP gene is firstly isolated in 11q13.5$11 \mathrm{q} 14$ chromosomal region in human breast carcinoma cells and defined as DI1S833E. The homologous sequence in mouse is located on Chromosome 7, region 7E-7F $[56,57]$. GARP gene that consists of two coding exons is expressed at two major transcripts of 4.4 and 2.8 kilobases respectively. The signal peptide and nine amino acid residues are encoded by the first exon. The second and the large one contains a putative extracellular region which encodes twenty leucine rich repeats (LRRs). The large exon also encodes a putative transmembrane domain followed by a short intracellular region $[6,58]$. GARP gene is expressed in various tissues including placenta, lung ,kidney, heart, liver, skeletal muscle, pancreas and lymphoid tissues[58]. Additionally, GARP gene is detected in multiple cell types such as megakaryocytes, platelets, B lymphocytes, T lymphocytes, mesenchymal stromal cells (MSCs) and human umbilical vein endothelial cells [59, 60]. Interestingly, an amplification of GARP gene has been found in tumors, particularly in invasive, metastatic or treatment-resistant tumors [61-64]. These may suggesting a potential role of this gene in regulating the aggressive ability of tumor.

\section{GARP EXPRESSION}

The extracellular portion of GARP is mostly composed of LRRs, thus GARP is also known as leucine rich repeats containing 32 (LRRC32). The structure of extracellular portion of GARP is similar to other members in LRR protein family, which play a role in proteinprotein interactions and signal transduction $[6,65]$. Protein structure prediction hints that the extracellular portion of GARP is high homology to the ectodomain of Toll-like receptor 3 (TLR-3), which is a horseshoe- shaped solenoid [66, 67]. GP96 serves as an essential chaperone for folding TLRs [68]. GP96 is also an essential chaperone for cell-surface GARP [69]. Similar to TLR3, three of five potential glycosylation sites of GARP are positioned on the concave face. The three potential glycosylation sites predict as potential ligand binding and oligomerization sites [70]. TLRs can recognize pathogen-associated molecular patterns and also bind with autologous molecules [71]. However, the possible ligands for GARP has not been reported.

GARP gene is detected in multiple cells types, however, only MSCs, hepatic stellate cells, platelets and Tregs are reported to express GARP on their membrane [6, $59,72]$. GARP expression has been proved to be regulated by microRNA because the distal part of 3' untranslated region (UTR) contains five highly conserved sequence [76]. MiR-142-3p, miR-181a, miR-185, miR-24 and miR-335 are considered to bind to the 3'UTR of GARP to repress its expression [77-79]. Whereafter, miR-142$3 p$ represses posttranscriptional regulation of GARP expression by argonaute 2-associated degradation of GARP mRNA [79]. Thus, downregulation of miRNA may be one way to induce GARP expression in Tregs.

\section{THE FUNCTION OF GARP IN TREGS}

\section{GARP increases the suppressive function of tregs}

The potential role of GARP in Tregs function has been analyzed in human Tregs. Compared with the GARPTregs, human $\mathrm{GARP}^{+}$Tregs are more potent in inhibiting the proliferation of Teffs in vitro. GARP ${ }^{+}$Tregs also secrete less IL-2 and IFN- $\gamma[37,67,73]$. GARP ${ }^{+}$Tregs is able to secrete abundant TGF- $\beta$ and IL-10 $[74,75]$. In addition, $\mathrm{GARP}^{+} \mathrm{CD} 154^{-}$Tregs are functionally much better than $\mathrm{CD} 4+\mathrm{CD} 25^{\text {high }}$ or $\mathrm{CD} 4+\mathrm{CD} 25^{\text {high }} \mathrm{CD} 127^{\text {low }}$ Tregs in vitro and in suppressing alloreactive immunoresponses in a humanized mouse model [36]. The suppressive function of Tregs are modestly and significantly impaired by GARP downregulation. The expression of CD27, CD83 and Foxp3 in Tregs are also significantly inhibited by GARP downregulation [67]. CD27 and CD83 contribute to the immunosuppressive function of Tregs by inducing Foxp3 expression [76, 77]. Tregs significantly suppress allergeninduced gut inflammation in a humanized mouse model. The suppressive effects of Tregs are further increased by activation before injection. Depletion of GARPexpressing cells among activated Tregs before injection and administration of GARP abrogate their inhibitory effects [78].

GARP overexpression endows non-Tregs with a partial or full regulatory phenotype and function. GARP overexpression in non-Tregs sustains the expression of Foxp3. GARP also increases the expression of other Treg-associated molecules including CD25, CTLA4, LGALS3, LGMN and CD27 in non-Tregs [7, 37]. In nonTregs, GARP overexpression decreases the production of IL- 2 and IFN- $\gamma$, and impairs the proliferative capacity. Furthermore, non-Tregs tranduced with GARP acquires suppressive activity. TCR stimulation further increases the surface expression of GARP on Tregs and intensifies effects of GARP on non-Tregs [67, 79]. Besides, genes representing a Treg-signature also upregulate in GARP transduction cells [67]. TGF- $\beta$-treated Teffs not express surface GARP upon TCR activation and is not suppressive [37]. These results suggest that GARP increases immunosuppressive function of Tregs, at least in part, but 
the mechanism of GARP-mediated inhibition of Tregs remains to be further studied.

\section{The relationship between GARP and Foxp3}

The relationship between GARP and Foxp3 is still in debate. The expression of Foxp3 appears to be not required for the expression of GARP because the expression of GARP is completely normal in Foxp3 knockdown Tregs $[8,37]$. Silencing GARP only attenuates Tregs suppressive activity, but not affect the expression of Foxp3. The suppressive function of $\mathrm{GARP}^{+}$Tregs are not altered by silencing Foxp3 [7]. Furthermore, following TCR activation, GARP/LAP are up-regulated on $\mathrm{CD}^{+}{ }^{+} \mathrm{Helios}^{+} \mathrm{T}$ cells regardless of Foxp3 expression $[74,80]$. These indicates that the expression of GARP and Foxp3 are independent probably, but all the experiments are carried out in vitro. What is the real situation or relationship between GARP and Foxp3 in vivo? It remains elusive and needs further studies to find out the truth.

However, controversy is always there. GARP expression is restricted to Foxp3+ population [40]. Foxp3 knockdown decreases the expression of GARP and suppressive function of Tregs [67]. Moreover, the induction of Foxp3 expression in Tregs precursors is accompanied by GARP $[81,82]$. This provides compelling evidence that the induction of GARP in Tregs is dependent on Foxp3 expression and GARP can also induce Foxp3 expression. We believe that there must be links between GARP and Foxp3 in the complex environment of human body.

\section{GARP is involved in the function and homeostasis of tregs via TGF- $\beta$}

\section{GARP promotes TGF- $\beta$ secretion and activation}

The secretion and activation of TGF- $\beta$ is a multistep process. TGF- $\beta$ is firstly synthesized as pro-TGF- $\beta$ precursor which exists as a homodimer in cells. Then, the homodimerized pro-TGF- $\beta$ is proteolytically cleaved by furin, resulting in the product called latent TGF- $\beta$. In latent TGF- $\beta$, LAP noncovalently binds to mature TGF- $\beta$ and prevents mature TGF- $\beta$ from binding to its receptor [9]. The release of mature TGF- $\beta$ from latent TGF- $\beta$ complex needs three steps [83]: 1) Disulfide linkage between latent TGF- $\beta$ to latent TGF- $\beta$ binding proteins (LTBPs). Two same cysteines, Cys-4 of the latent TGF- $\beta$ dimmer, can link to the cysteines of LTBPs through disulfide bond [84]. 2) Combination between integrin and latent TGF- $\beta$. The structure of latent TGF- $\beta$ is reported in 2011. The whole structure is a ring-like shape and mature TGF- $\beta$ is in the centre of the ring [85]. Cys-4 located at the bottom of the ring would be linked to LTBPs. The
RGD motifs located to each shoulder of the ring can be recognized by integrin expressed on cell surface [86]. 3) Contractile force. Since latent TGF- $\beta$ and LTBPs are fixed on cell surface and extracellular matrix cytoskeleton respectively, the contractile force is able to release mature TGF- $\beta$ from latent TGF- $\beta$ [87]. However, contractile force is not always required for TGF- $\beta$ activation because the metalloprotease 14 has been shown to cleave latent TGF- $\beta$ without contractile force [88].

It has been proved that GARP is essential for the surface expression of latent TGF- $\beta$ on Tregs. GARP expressed on surface of Tregs possesses similar role as LTBPs. GARP directly binds to latent TGF- $\beta$ through disulfide linkage and noncovalent association [73]. The latent TGF- $\beta$ is anchored on Tregs membrane, so the GARP associated TGF- $\beta$ can describe as membrane bound TGF- $\beta$ (mTGF- $\beta$ ). Cys-192 and Cys-331 of GARP disufide link to Cys-4 of latent TGF- $\beta$. Though Cys-192 and Cys-331 mutate to alanine, GARP can still noncovalently associate with latent TGF- $\beta$ to prevent TGF- $\beta$ secretion. This noncovalent association between GARP and latent TGF- $\beta$ is sufficient for GARP to outcompete LTBPs $[73,89]$. It seems that the disulfidelinkage is unnecessary for binding between GARP and latent TGF- $\beta$. In fact, the disulfide-linkage is indispensable for the release of mature TGF- $\beta$ because the mutant is unable to activate TGF- $\beta$ [89]. The RGD motif in LAP is recognized by integrin $\alpha_{v} \beta_{6}$ and $\alpha_{\mathrm{v}} \beta_{8}[90,91]$, thus inducing the release of active TGF- $\beta$ from latent TGF- $\beta /$ GARP complex $[92,93]$. Despite soluble GARP (sGARP) forms an complex with latent TGF- $\beta$, sGARP is unable to support $\alpha_{v} \beta_{6}$ or $\alpha_{v} \beta_{8}$ mediated TGF- $\beta$ activation [73]. This suggests that membrane form of GARP not sGARP is necessary for TGF- $\beta$ activation. Overall, membrane GARP is not enough to release TGF- $\beta$. The recognition of RGD motif by integrin and the linkage between surface GARP and latent TGF- $\beta$ are all required to TGF- $\beta$ activation [73].

\section{TGF- $\beta$ participates in tregs function and homeostasis}

Mature TGF- $\beta$ released from Tregs can act on target cells in paracrine manner and plays a critical role for function of Tregs. TGF- $\beta$ inhibits Teffs proliferation and cytokines production [94]. It also suppresses the differentiation of Teffs into Th1 and Th17 cells [95]. Besides, Tregs suppress anti-tumor immunoresponses and $\mathrm{CD}^{+} \mathrm{T}$ cells proliferation via TGF- $\beta$. TGF- $\beta$ receptor negative $\mathrm{CD} 8^{+} \mathrm{T}$ cells abrogate this anti-tumor immunoresponses [96, 97]. Because TGF- $\beta$ release process from Tregs is mediated by GARP, GARP may play a role in Tregs function through TGF- $\beta$.

Interestingly, studies have certificated that mTGF- $\beta$ is involved in cell-contact dependent immunosuppression of Tregs [98-100]. Feline Tregs from immunodeficiency virus infection inhibit the proliferation and the cytokines production of Th cells. These Tregs are able to convert 
Th cells into iTregs through GARP-mTGF- $\beta$ [101, 102]. Moreover, GARP-mTGF- $\beta$ complex rather than secreted TGF- $\beta$ from Tregs has the ability to induce Th17 differentiation. On the other hand, GARP can discriminate $\mathrm{CD} 25^{+} \mathrm{T}$ cells that contain high levels of IL-17 secreting cells [81]. Two anti-GARP monoclonal antibodies recognize a conformational epitope within GARP-mTGF- $\beta$ complex and block the production of active TGF- $\beta$ from human Tregs. The two antibodies can effectively inhibit the immunosuppressive activity of human Tregs in a model of xenogeneic graft-versus- host disease in NSG mouse [103]. But the function of GARPmTGF- $\beta$ complex is still unclear and further explorations are needed.

TGF- $\beta$ from Tregs is also able to act on Tregs themselves, maintaining the function and homeostasis of Tregs [104]. TGF- $\beta$ specific transcriptional prolifing and phosphorylated Smads are detected in human and mice Tregs [105]. Both Smad2 and Smad3 have the capacity to induce the expression of Foxp3 [106-108]. Besides, the interaction of Smad3 and CNS1 (an enhancer region of Foxp3 gene) is essential for maintaining Tregs number and homeostasis in vivo $[39,108]$. Moreover, Tregs of TGF- $\beta$ receptor-deficient has increaesd apoptosis [104, 109]. These uncover that TGF- $\beta$ from Tregs forms the autocrine and positive TGF- $\beta$ loop, maintaining the function and homeostasis of Tregs.

\section{IMPLICATIONS IN CANCER IMMUNOTHERAPY}

In mice with colitis-associated colon cancer, Tregs from tumor express higher GARP and CTLA-4. Theses Tregs possess strong suppressive activity. The frequency and cytotoxic activity of $\mathrm{CD} 8^{+} \mathrm{T}$ cells are enhanced by the transient ablation of $\mathrm{GARP}^{+} \mathrm{CTLA}-4^{+}$Tregs, thus attenuating tumor growth [110]. In head and neck squamous cell carcinoma patients, the frequency of highly suppressive Tregs with upregulated GARP and LAP is increased by adjuvant chemoradiotherapy (CRT). These Tregs from CRT patients are resistant to cisplatin and activation induced cell death. Additionally, these Tregs participate in suppressing anti-tumor immunoresponses and recurrence of cancer [111]. Moreover, the frequency of GARP ${ }^{+} \mathrm{Foxp}^{+}$Tregs is highly elevated in peripheral blood of patients with advanced hepatocellular carcinoma. The depletion of $\mathrm{GARP}^{+}$Tregs in combination with CTLA4 restores $\mathrm{CD}^{+} \mathrm{T}$ cell-dependent granzyme production [112]. CD8 ${ }^{+} \mathrm{T}$ cells expressing high levels of granzyme $\mathrm{B}$ are associated with prolonged progression free survival after combination of rituximab and chemotherapy in follicular lymphoma patients [113]. Thus, GARP together with other molecules in depleting Tregs or attenuating their suppressive activity may represent a new target in cancer immunotherapy.

\section{CONCLUSIONS}

The discovery of surface GARP on Tregs sets a new stage in elucidating functions and mechanism of Tregs. GARP provides a regulatory network between Tregs and its targets including Tregs themselves. GARP ${ }^{+}$Tregs may be used as targets especially in tumor immunotherapy. We should notice that the regulaory function mediated by GARP-TGF- $\beta$ pathway in Tregs is not the whole story but just a part. Many other membrane molecules such as CTLA-4 and other checkpoints are also reported to mediate the suppressive function of Tregs. However, GARP-deficient Tregs are present in normal numbers in peripheral tissues of mice. Besides, these GARP-deficient Tregs develop normally and are as effective as Tregs from WT mice in suppressing CD4+CD25- responder cell proliferation [81]. It indicates that GARP is not absolutely required for the suppressive function of Tregs. But until now our understanding of GARP is very little and not very clear. The thorough and clear elucidation is a vital and difficult challenge in the future. Further studies may make it become a crucial molecule for Tregs even for the isolation of Tregs.

\section{ACKNOWLEDGMENTS}

This work was supported by grants from the Natural Science Foundation of China (No.31471341).

\section{CONFLICTS OF INTEREST}

The authors declare no conflict of interest.

\section{REFERENCES}

1. Schmetterer KG, Neunkirchner A and Pickl WF. Naturally occurring regulatory $\mathrm{T}$ cells: markers, mechanisms, and manipulation. FASEB journal. 2012; 26(6):2253-2276.

2. Bluestone JA and Abbas AK. Natural versus adaptive regulatory $\mathrm{T}$ cells. Nature reviews Immunology. 2003; 3(3):253-257.

3. Bilate AM and Lafaille JJ. Induced CD4+Foxp3+ regulatory $\mathrm{T}$ cells in immune tolerance. Annual review of immunology. 2012; 30:733-758.

4. Horwitz DA, Zheng SG and Gray JD. Natural and TGFbeta-induced Foxp3(+)CD4(+) CD25(+) regulatory T cells are not mirror images of each other. Trends in immunology. 2008; 29(9):429-435.

5. Chen X and Oppenheim JJ. Resolving the identity myth: key markers of functional CD4+FoxP3+ regulatory T cells. International immunopharmacology. 2011; 11(10):14891496.

6. Roubin R, Pizette S, Ollendorff V, Planche J, Birnbaum $\mathrm{D}$ and Delapeyriere O. Structure and developmental expression of mouse Garp, a gene encoding a new leucine- 
rich repeat-containing protein. The International journal of developmental biology. 1996; 40(3):545-555.

7. Wang R, Wan Q, Kozhaya L, Fujii H and Unutmaz D. Identification of a regulatory $\mathrm{T}$ cell specific cell surface molecule that mediates suppressive signals and induces Foxp3 expression. PloS one. 2008; 3(7):e2705.

8. Tran DQ, Andersson J, Wang R, Ramsey H, Unutmaz D and Shevach EM. GARP (LRRC32) is essential for the surface expression of latent TGF-beta on platelets and activated FOXP3+ regulatory $\mathrm{T}$ cells. Proceedings of the National Academy of Sciences of the United States of America. 2009; 106(32):13445-13450.

9. Stockis J, Colau D, Coulie PG and Lucas S. Membrane protein GARP is a receptor for latent TGF-beta on the surface of activated human Treg. European journal of immunology. 2009; 39(12):3315-3322.

10. Gershon RK and Kondo K. Cell interactions in the induction of tolerance: the role of thymic lymphocytes. Immunology. 1970; 18(5):723-737.

11. Sakaguchi S, Sakaguchi N, Asano M, Itoh M and Toda M. Immunologic self-tolerance maintained by activated $\mathrm{T}$ cells expressing IL-2 receptor alpha-chains (CD25). Breakdown of a single mechanism of self-tolerance causes various autoimmune diseases. Journal of immunology. 1995; 155(3):1151-1164.

12. Suri-Payer E, Amar AZ, Thornton AM and Shevach EM. $\mathrm{CD} 4+\mathrm{CD} 25+\mathrm{T}$ cells inhibit both the induction and effector function of autoreactive $\mathrm{T}$ cells and represent a unique lineage of immunoregulatory cells. Journal of immunology. 1998; 160(3):1212-1218.

13. Almeida AR, Legrand N, Papiernik M and Freitas AA. Homeostasis of peripheral CD4+ T cells: IL-2R alpha and IL-2 shape a population of regulatory cells that controls CD4+ T cell numbers. Journal of immunology. 2002; 169(9):4850-4860.

14. Baecher-Allan C, Brown JA, Freeman GJ and Hafler DA. CD4+CD25high regulatory cells in human peripheral blood. Journal of immunology. 2001; 167(3):1245-1253.

15. Baecher-Allan C, Viglietta V and Hafler DA. Inhibition of human CD4(+)CD25(+high) regulatory $\mathrm{T}$ cell function. Journal of immunology. 2002; 169(11):6210-6217.

16. Ng WF, Duggan PJ, Ponchel F, Matarese G, Lombardi G, Edwards AD, Isaacs JD and Lechler RI. Human CD4(+) CD25(+) cells: a naturally occurring population of regulatory T cells. Blood. 2001; 98(9):2736-2744.

17. Wing K, Onishi Y, Prieto-Martin P, Yamaguchi T, Miyara M, Fehervari Z, Nomura T and Sakaguchi S. CTLA-4 control over Foxp3+ regulatory $\mathrm{T}$ cell function. Science. 2008; 322(5899):271-275.

18. Redpath SA, van der Werf N, Cervera AM, MacDonald AS, Gray D, Maizels RM and Taylor MD. ICOS controls Foxp3(+) regulatory T-cell expansion, maintenance and IL10 production during helminth infection. European journal of immunology. 2013; 43(3):705-715.
19. van Mierlo GJ, Scherer HU, Hameetman M, Morgan ME, Flierman R, Huizinga TW and Toes RE. Cutting edge: TNFR-shedding by CD4+CD25+ regulatory T cells inhibits the induction of inflammatory mediators. Journal of immunology. 2008; 180(5):2747-2751.

20. McHugh RS, Whitters MJ, Piccirillo CA, Young DA, Shevach EM, Collins M and Byrne MC. CD4(+)CD25(+) immunoregulatory $\mathrm{T}$ cells: gene expression analysis reveals a functional role for the glucocorticoid-induced TNF receptor. Immunity. 2002; 16(2):311-323.

21. Hamano R, Huang J, Yoshimura T, Oppenheim JJ and Chen $\mathrm{X}$. TNF optimally activatives regulatory $\mathrm{T}$ cells by inducing TNF receptor superfamily members TNFR2, 4-1BB and OX40. European journal of immunology. 2011; 41(7):20102020.

22. Camisaschi C, Casati C, Rini F, Perego M, De Filippo A, Triebel F, Parmiani G, Belli F, Rivoltini L and Castelli C. LAG-3 expression defines a subset of CD4(+)CD25(high) Foxp3(+) regulatory $\mathrm{T}$ cells that are expanded at tumor sites. Journal of immunology. 2010; 184(11):6545-6551.

23. Tran DQ, Andersson J, Hardwick D, Bebris L, Illei GG and Shevach EM. Selective expression of latency-associated peptide (LAP) and IL-1 receptor type I/II (CD121a/ CD121b) on activated human FOXP3+ regulatory T cells allows for their purification from expansion cultures. Blood. 2009; 113(21):5125-5133.

24. Fontenot JD, Rasmussen JP, Williams LM, Dooley JL, Farr AG and Rudensky AY. Regulatory T cell lineage specification by the forkhead transcription factor foxp3. Immunity. 2005; 22(3):329-341.

25. Thornton AM, Korty PE, Tran DQ, Wohlfert EA, Murray PE, Belkaid Y and Shevach EM. Expression of Helios, an Ikaros transcription factor family member, differentiates thymic-derived from peripherally induced Foxp3+ T regulatory cells. Journal of immunology. 2010; 184(7):3433-3441.

26. Hartigan-O'Connor DJ, Poon C, Sinclair E and McCune JM. Human CD4+ regulatory $\mathrm{T}$ cells express lower levels of the IL-7 receptor alpha chain (CD127), allowing consistent identification and sorting of live cells. Journal of immunological methods. 2007; 319(1-2):41-52.

27. Garcia Santana CA, Tung JW and Gulnik S. Human treg cells are characterized by low/negative CD6 expression. Cytometry Part A. 2014; 85(10):901-908.

28. Salgado FJ, Perez-Diaz A, Villanueva NM, Lamas O, Arias $\mathrm{P}$ and Nogueira M. CD26: a negative selection marker for human Treg cells. Cytometry Part A. 2012; 81(10):843-855.

29. Kleinewietfeld M, Starke M, Di Mitri D, Borsellino G, Battistini L, Rotzschke O and Falk K. CD49d provides access to "untouched" human Foxp3+ Treg free of contaminating effector cells. Blood. 2009; 113(4):827-836.

30. Williams LM and Rudensky AY. Maintenance of the Foxp3-dependent developmental program in mature regulatory $\mathrm{T}$ cells requires continued expression of Foxp3. 
Nature immunology. 2007; 8(3):277-284.

31. Allan SE, Crome SQ, Crellin NK, Passerini L, Steiner TS, Bacchetta R, Roncarolo MG and Levings MK. Activationinduced FOXP3 in human $\mathrm{T}$ effector cells does not suppress proliferation or cytokine production. International immunology. 2007; 19(4):345-354.

32. Allan SE, Passerini L, Bacchetta R, Crellin N, Dai M, Orban PC, Ziegler SF, Roncarolo MG and Levings MK. The role of 2 FOXP3 isoforms in the generation of human CD4+ Tregs. The Journal of clinical investigation. 2005; 115(11):3276-3284.

33. Gavin MA, Torgerson TR, Houston E, DeRoos P, Ho WY, Stray-Pedersen A, Ocheltree EL, Greenberg PD, Ochs HD and Rudensky AY. Single-cell analysis of normal and FOXP3-mutant human T cells: FOXP3 expression without regulatory T cell development. Proceedings of the National Academy of Sciences of the United States of America. 2006; 103(17):6659-6664.

34. Tran DQ, Ramsey H and Shevach EM. Induction of FOXP3 expression in naive human CD4+FOXP3 T cells by T-cell receptor stimulation is transforming growth factor-beta dependent but does not confer a regulatory phenotype. Blood. 2007; 110(8):2983-2990.

35. Ramsdell F and Ziegler SF. FOXP3 and scurfy: how it all began. Nature reviews Immunology. 2014; 14(5):343-349.

36. Noyan F, Lee YS, Zimmermann K, Hardtke-Wolenski M, Taubert R, Warnecke G, Knoefel AK, Schulde E, Olek $\mathrm{S}$, Manns MP and Jaeckel E. Isolation of human antigenspecific regulatory $\mathrm{T}$ cells with high suppressive function. European journal of immunology. 2014; 44(9):2592-2602.

37. Wang R, Kozhaya L, Mercer F, Khaitan A, Fujii H and Unutmaz D. Expression of GARP selectively identifies activated human FOXP3+ regulatory T cells. Proceedings of the National Academy of Sciences of the United States of America. 2009; 106(32):13439-13444.

38. Zhou AX, Kozhaya L, Fujii H and Unutmaz D. GARPTGF-beta complexes negatively regulate regulatory $\mathrm{T}$ cell development and maintenance of peripheral CD4+ T cells in vivo. Journal of immunology. 2013; 190(10):5057-5064.

39. Zheng Y, Josefowicz S, Chaudhry A, Peng XP, Forbush $\mathrm{K}$ and Rudensky AY. Role of conserved non-coding DNA elements in the Foxp3 gene in regulatory T-cell fate. Nature. 2010; 463(7282):808-812.

40. Frentsch M, Arbach O, Kirchhoff D, Moewes B, Worm M, Rothe M, Scheffold A and Thiel A. Direct access to CD4+ $\mathrm{T}$ cells specific for defined antigens according to CD154 expression. Nature medicine. 2005; 11(10):1118-1124.

41. Takahashi T, Tagami T, Yamazaki S, Uede T, Shimizu J, Sakaguchi N, Mak TW and Sakaguchi S. Immunologic self-tolerance maintained by $\mathrm{CD} 25(+) \mathrm{CD} 4(+)$ regulatory $\mathrm{T}$ cells constitutively expressing cytotoxic $\mathrm{T}$ lymphocyteassociated antigen 4 . The Journal of experimental medicine. 2000; 192(2):303-310.

42. Burmeister Y, Lischke T, Dahler AC, Mages HW, Lam KP,
Coyle AJ, Kroczek RA and Hutloff A. ICOS controls the pool size of effector-memory and regulatory T cells. Journal of immunology. 2008; 180(2):774-782.

43. Vocanson M, Rozieres A, Hennino A, Poyet G, Gaillard V, Renaudineau S, Achachi A, Benetiere J, Kaiserlian D, Dubois B and Nicolas JF. Inducible costimulator (ICOS) is a marker for highly suppressive antigen-specific $\mathrm{T}$ cells sharing features of $\mathrm{TH} 17 / \mathrm{TH} 1$ and regulatory $\mathrm{T}$ cells. The Journal of allergy and clinical immunology. 2010; 126(2):280-289, 289.e281-287.

44. Ito T, Hanabuchi S, Wang YH, Park WR, Arima K, Bover L, Qin FX, Gilliet M and Liu YJ. Two functional subsets of FOXP3 + regulatory $\mathrm{T}$ cells in human thymus and periphery. Immunity. 2008; 28(6):870-880.

45. Chen X, Subleski JJ, Kopf H, Howard OM, Mannel DN and Oppenheim JJ. Cutting edge: expression of TNFR2 defines a maximally suppressive subset of mouse CD4+CD25+FoxP3+ $\mathrm{T}$ regulatory cells: applicability to tumor-infiltrating $\mathrm{T}$ regulatory cells. Journal of immunology. 2008; 180(10):6467-6471.

46. Chen X, Hamano R, Subleski JJ, Hurwitz AA, Howard OM and Oppenheim JJ. Expression of costimulatory TNFR2 induces resistance of CD4+FoxP3- conventional T cells to suppression by CD4+FoxP3+ regulatory $\mathrm{T}$ cells. Journal of immunology. 2010; 185(1):174-182.

47. Shimizu J, Yamazaki S, Takahashi T, Ishida $\mathrm{Y}$ and Sakaguchi S. Stimulation of CD25(+)CD4(+) regulatory T cells through GITR breaks immunological self-tolerance. Nature immunology. 2002; 3(2):135-142.

48. Liao G, Detre C, Berger SB, Engel P, de Waal Malefyt R, Herzog RW, Bhan AK and Terhorst C. Glucocorticoidinduced tumor necrosis factor receptor family-related protein regulates $\mathrm{CD} 4(+) \mathrm{T}$ cell-mediated colitis in mice. Gastroenterology. 2012; 142(3):582-591.e588.

49. Schoenbrunn A, Frentsch M, Kohler S, Keye J, Dooms H, Moewes B, Dong J, Loddenkemper C, Sieper J, Wu P, Romagnani C, Matzmohr N and Thiel A. A converse 4-1BB and CD40 ligand expression pattern delineates activated regulatory $\mathrm{T}$ cells (Treg) and conventional $\mathrm{T}$ cells enabling direct isolation of alloantigen-reactive natural Foxp3+ Treg. Journal of immunology. 2012; 189(12):5985-5994.

50. Croft $\mathrm{M}$. The role of TNF superfamily members in T-cell function and diseases. Nature reviews Immunology. 2009; 9(4):271-285.

51. Huang CT, Workman CJ, Flies D, Pan X, Marson AL, Zhou G, Hipkiss EL, Ravi S, Kowalski J, Levitsky HI, Powell JD, Pardoll DM, Drake CG and Vignali DA. Role of LAG-3 in regulatory T cells. Immunity. 2004; 21(4):503-513.

52. Workman CJ, Rice DS, Dugger KJ, Kurschner C and Vignali DA. Phenotypic analysis of the murine CD4related glycoprotein, CD223 (LAG-3). European journal of immunology. 2002; 32(8):2255-2263.

53. D'Ambrosio A, Cossu A, Amendola A, Zandri A, Butera A, Sanchez M, Biffoni M, Pronio A, Montesani C, Kohn 
A, Pica R and Boirivant M. Lamina propria CD4+LAP+ regulatory $\mathrm{T}$ cells are increased in active ulcerative colitis but show increased IL-17 expression and reduced suppressor activity. Journal of Crohn's \& colitis. 2016; 10:346-53. doi: 10.1093/ecco-jcc/jjv216.

54. Simonetta F, Chiali A, Cordier C, Urrutia A, Girault I, Bloquet $\mathrm{S}$, Tanchot $\mathrm{C}$ and Bourgeois $\mathrm{C}$. Increased CD127 expression on activated FOXP3+CD4+ regulatory T cells. European journal of immunology. 2010; 40(9):2528-2538.

55. Himmel ME, MacDonald KG, Garcia RV, Steiner TS and Levings MK. Helios+ and Helios- cells coexist within the natural FOXP3 + T regulatory cell subset in humans. Journal of immunology. 2013; 190(5):2001-2008.

56. Ollendorff V, Szepetowski P, Mattei MG, Gaudray P and Birnbaum D. New gene in the homologous human 11q13-q14 and mouse $7 \mathrm{~F}$ chromosomal regions. Mammalian genome. 1992; 2(3):195-200.

57. Seldin MF, Saunders AM, Rochelle JM and Howard TA. A proximal mouse chromosome 9 linkage map that further defines linkage groups homologous with segments of human chromosomes 11, 15, and 19. Genomics. 1991; 9(4):678-685.

58. Ollendorff $\mathrm{V}$, Noguchi $\mathrm{T}$, deLapeyriere $\mathrm{O}$ and Birnbaum D. The GARP gene encodes a new member of the family of leucine-rich repeat-containing proteins. Cell growth \& differentiation. 1994; 5(2):213-219.

59. Macaulay IC, Tijssen MR, Thijssen-Timmer DC, Gusnanto A, Steward M, Burns P, Langford CF, Ellis PD, Dudbridge F, Zwaginga JJ, Watkins NA, van der Schoot CE and Ouwehand WH. Comparative gene expression profiling of in vitro differentiated megakaryocytes and erythroblasts identifies novel activatory and inhibitory platelet membrane proteins. Blood. 2007; 109(8):3260-3269.

60. Carrillo-Galvez AB, Cobo M, Cuevas-Ocana S, GutierrezGuerrero A, Sanchez-Gilabert A, Bongarzone P, GarciaPerez A, Munoz P, Benabdellah K, Toscano MG, Martin $\mathrm{F}$ and Anderson P. Mesenchymal stromal cells express GARP/LRRC32 on their surface: effects on their biology and immunomodulatory capacity. Stem cells. 2015; 33(1):183-195.

61. Liu CJ, Lin SC, Chen YJ, Chang KM and Chang KW. Array-comparative genomic hybridization to detect genomewide changes in microdissected primary and metastatic oral squamous cell carcinomas. Molecular carcinogenesis. 2006; 45(10):721-731.

62. Martinez-Cardus A, Martinez-Balibrea E, Bandres E, Malumbres R, Gines A, Manzano JL, Taron M, GarciaFoncillas J and Abad A. Pharmacogenomic approach for the identification of novel determinants of acquired resistance to oxaliplatin in colorectal cancer. Molecular cancer therapeutics. 2009; 8(1):194-202.

63. Lassmann S, Weis R, Makowiec F, Roth J, Danciu M, Hopt $\mathrm{U}$ and Werner M. Array CGH identifies distinct DNA copy number profiles of oncogenes and tumor suppressor genes in chromosomal- and microsatellite-unstable sporadic colorectal carcinomas. Journal of molecular medicine. 2007; 85(3):293-304.

64. Rodriguez C, Hughes-Davies L, Valles H, Orsetti B, Cuny M, Ursule L, Kouzarides T and Theillet C. Amplification of the BRCA2 pathway gene EMSY in sporadic breast cancer is related to negative outcome. Clinical cancer research. 2004; 10(17):5785-5791.

65. Hickey MJ, Hagen FS, Yagi M and Roth GJ. Human platelet glycoprotein $\mathrm{V}$ : characterization of the polypeptide and the related $\mathrm{Ib}-\mathrm{V}-\mathrm{IX}$ receptor system of adhesive, leucine-rich glycoproteins. Proceedings of the National Academy of Sciences of the United States of America. 1993; 90(18):8327-8331.

66. Bell JK, Botos I, Hall PR, Askins J, Shiloach J, Segal DM and Davies DR. The molecular structure of the Toll-like receptor 3 ligand-binding domain. Proceedings of the National Academy of Sciences of the United States of America. 2005; 102(31):10976-10980.

67. Probst-Kepper M, Geffers R, Kroger A, Viegas N, Erck C, Hecht HJ, Lunsdorf H, Roubin R, Moharregh-Khiabani D, Wagner K, Ocklenburg F, Jeron A, Garritsen H, Arstila TP, Kekalainen E, Balling R, et al. GARP: a key receptor controlling FOXP3 in human regulatory T cells. Journal of cellular and molecular medicine. 2009; 13(9b):3343-3357.

68. Yang Y, Liu B, Dai J, Srivastava PK, Zammit DJ, Lefrancois L and Li Z. Heat shock protein gp96 is a master chaperone for toll-like receptors and is important in the innate function of macrophages. Immunity. 2007; 26(2):215-226.

69. Zhang Y, Wu BX, Metelli A, Thaxton JE, Hong F, Rachidi S, Ansa-Addo E, Sun S, Vasu C, Yang Y, Liu B and Li Z. GP96 is a GARP chaperone and controls regulatory $\mathrm{T}$ cell functions. The Journal of clinical investigation. 2015; 125(2):859-869.

70. Ernst A, Appleton BA, Ivarsson Y, Zhang Y, Gfeller D, Wiesmann C and Sidhu SS. A structural portrait of the PDZ domain family. Journal of molecular biology. 2014; 426(21):3509-3519.

71. Chang ZL. Important aspects of Toll-like receptors, ligands and their signaling pathways. Inflammation research. 2010; 59(10):791-808.

72. Li Y, Kim BG, Qian S, Letterio JJ, Fung JJ, Lu L and Lin F. Hepatic Stellate Cells Inhibit T Cells through Active TGFbeta1 from a Cell Surface-Bound Latent TGF-beta1/GARP Complex. Journal of immunology. 2015; 195(6):2648-2656.

73. Wang R, Zhu J, Dong X, Shi M, Lu C and Springer TA. GARP regulates the bioavailability and activation of TGFbeta. Molecular biology of the cell. 2012; 23(6):11291139.

74. Rappl G, Pabst S, Riemann D, Schmidt A, Wickenhauser C, Schutte W, Hombach AA, Seliger B, Grohe C and Abken H. Regulatory $\mathrm{T}$ cells with reduced repressor capacities are extensively amplified in pulmonary sarcoid lesions and sustain granuloma formation. Clinical immunology. 2011; 
140(1):71-83.

75. Zhong $\mathrm{Y}$, Tang $\mathrm{H}$, Wang $\mathrm{X}$, Zeng Q, Liu Y, Zhao X, Yu $\mathrm{K}$, Shi $\mathrm{H}$, Zhu $\mathrm{R}$ and Mao $\mathrm{X}$. Intranasal Immunization with Heat Shock Protein 60 Induces CD4+CD25+GARP+ and Type-1 Regulatory $\mathrm{T}$ Cells and Inhibits Early Atherosclerosis. Clinical and experimental immunology. 2016; 183:452-68. doi: 10.1111/cei.12726.

76. Reinwald S, Wiethe C, Westendorf AM, Breloer M, Probst-Kepper M, Fleischer B, Steinkasserer A, Buer J and Hansen W. CD83 expression in CD4+ T cells modulates inflammation and autoimmunity. Journal of immunology. 2008; 180(9):5890-5897.

77. Yang ZZ, Novak AJ, Ziesmer SC, Witzig TE and Ansell SM. CD70+ non-Hodgkin lymphoma B cells induce Foxp3 expression and regulatory function in intratumoral CD4+CD25 T cells. Blood. 2007; 110(7):2537-2544.

78. Eschborn M, Weigmann B, Reissig S, Waisman A, Saloga $\mathrm{J}$ and Bellinghausen I. Activated glycoprotein A repetitions predominant (GARP)-expressing regulatory $T$ cells inhibit allergen-induced intestinal inflammation in humanized mice. The Journal of allergy and clinical immunology. 2015; 136(1):159-168.

79. Ruprecht CR, Gattorno M, Ferlito F, Gregorio A, Martini A, Lanzavecchia A and Sallusto F. Coexpression of CD25 and CD27 identifies FoxP3+ regulatory T cells in inflamed synovia. The Journal of experimental medicine. 2005; 201(11):1793-1803.

80. Elkord E, Abd Al Samid M and Chaudhary B. Helios, and not FoxP3, is the marker of activated Tregs expressing GARP/LAP. Oncotarget. 2015; 6(24):20026-20036. doi: 10.18632/oncotarget.4771.

81. Edwards JP, Fujii H, Zhou AX, Creemers J, Unutmaz D and Shevach EM. Regulation of the expression of GARP/ latent TGF-betal complexes on mouse $\mathrm{T}$ cells and their role in regulatory $\mathrm{T}$ cell and Th17 differentiation. Journal of immunology. 2013; 190(11):5506-5515.

82. Lee SY, Cho ML, Oh HJ, Ryu JG, Park MJ, Jhun JY, Park MK, Stone JC, Ju JH, Hwang SY, Park SH, Surh CD and Kim HY. Interleukin-2/anti-interleukin-2 monoclonal antibody immune complex suppresses collagen-induced arthritis in mice by fortifying interleukin-2/STAT5 signalling pathways. Immunology. 2012; 137(4):305-316.

83. Buscemi L, Ramonet D, Klingberg F, Formey A, SmithClerc J, Meister JJ and Hinz B. The single-molecule mechanics of the latent TGF-beta1 complex. Current biology. 2011; 21(24):2046-2054.

84. Rifkin DB. Latent transforming growth factor-beta (TGF-beta) binding proteins: orchestrators of TGF-beta availability. The Journal of biological chemistry. 2005; 280(9):7409-7412.

85. Shi M, Zhu J, Wang R, Chen X, Mi L, Walz T and Springer TA. Latent TGF-beta structure and activation. Nature. 2011; 474(7351):343-349.

86. Wipff PJ and Hinz B. Integrins and the activation of latent transforming growth factor beta1 - an intimate relationship. European journal of cell biology. 2008; 87(8-9):601-615.

87. Yoshinaga K, Obata H, Jurukovski V, Mazzieri R, Chen Y, Zilberberg L, Huso D, Melamed J, Prijatelj P, Todorovic V, Dabovic B and Rifkin DB. Perturbation of transforming growth factor (TGF)-betal association with latent TGFbeta binding protein yields inflammation and tumors. Proceedings of the National Academy of Sciences of the United States of America. 2008; 105(48):18758-18763.

88. Worthington JJ, Klementowicz JE and Travis MA. TGFbeta: a sleeping giant awoken by integrins. Trends in biochemical sciences. 2011; 36(1):47-54.

89. Gauthy E, Cuende J, Stockis J, Huygens C, Lethe B, Collet JF, Bommer G, Coulie PG and Lucas S. GARP is regulated by miRNAs and controls latent TGF-beta1 production by human regulatory T cells. PloS one. 2013; 8(9):e76186.

90. Giacomini MM, Travis MA, Kudo M and Sheppard D. Epithelial cells utilize cortical actin/myosin to activate latent TGF-beta through integrin alpha(v)beta(6)dependent physical force. Experimental cell research. 2012; 318(6):716-722.

91. Paidassi H, Acharya M, Zhang A, Mukhopadhyay S, Kwon M, Chow C, Stuart LM, Savill J and Lacy-Hulbert A. Preferential expression of integrin alphavbeta8 promotes generation of regulatory $\mathrm{T}$ cells by mouse $\mathrm{CD} 103+$ dendritic cells. Gastroenterology. 2011; 141(5):1813-1820.

92. Travis MA, Reizis B, Melton AC, Masteller E, Tang Q, Proctor JM, Wang Y, Bernstein X, Huang X, Reichardt LF, Bluestone JA and Sheppard D. Loss of integrin alpha(v) beta 8 on dendritic cells causes autoimmunity and colitis in mice. Nature. 2007; 449(7160):361-365.

93. Edwards JP, Thornton AM and Shevach EM. Release of active TGF-betal from the latent TGF-beta1/GARP complex on $\mathrm{T}$ regulatory cells is mediated by integrin beta8. Journal of immunology. 2014; 193(6):2843-2849.

94. Nakamura K, Kitani A, Fuss I, Pedersen A, Harada N, Nawata $\mathrm{H}$ and Strober W. TGF-beta 1 plays an important role in the mechanism of $\mathrm{CD} 4+\mathrm{CD} 25+$ regulatory $\mathrm{T}$ cell activity in both humans and mice. Journal of immunology. 2004; 172(2):834-842.

95. Li MO, Wan YY and Flavell RA. T cell-produced transforming growth factor-betal controls $\mathrm{T}$ cell tolerance and regulates Th1- and Th17-cell differentiation. Immunity. 2007; 26(5):579-591.

96. Chen ML, Pittet MJ, Gorelik L, Flavell RA, Weissleder R, von Boehmer $\mathrm{H}$ and Khazaie K. Regulatory T cells suppress tumor-specific CD8 T cell cytotoxicity through TGF-beta signals in vivo. Proceedings of the National Academy of Sciences of the United States of America. 2005; 102(2):419424.

97. Mempel TR, Pittet MJ, Khazaie K, Weninger W, Weissleder $\mathrm{R}$, von Boehmer $\mathrm{H}$ and von Andrian UH. Regulatory $\mathrm{T}$ cells reversibly suppress cytotoxic $\mathrm{T}$ cell function independent of effector differentiation. Immunity. 2006; 25(1):129-141. 
98. Shen E, Zhao K, Wu C and Yang B. The suppressive effect of CD25+Treg cells on Th1 differentiation requires cellcell contact partially via TGF-beta production. Cell biology international. 2011; 35(7):705-712.

99. Nakamura K, Kitani A and Strober W. Cell contactdependent immunosuppression by $\mathrm{CD} 4(+) \mathrm{CD} 25(+)$ regulatory $\mathrm{T}$ cells is mediated by cell surface-bound transforming growth factor beta. The Journal of experimental medicine. 2001; 194(5):629-644.

100. Gregg RK, Jain R, Schoenleber SJ, Divekar R, Bell JJ, Lee $\mathrm{HH}, \mathrm{Yu} \mathrm{P}$ and Zaghouani H. A sudden decline in active membrane-bound TGF-beta impairs both $\mathrm{T}$ regulatory cell function and protection against autoimmune diabetes. Journal of immunology. 2004; 173(12):7308-7316.

101. Miller MM, Fogle JE, Ross $\mathrm{P}$ and Tompkins MB. Feline glycoprotein A repetitions predominant anchors transforming growth factor beta on the surface of activated $\mathrm{CD} 4(+) \mathrm{CD} 25(+)$ regulatory $\mathrm{T}$ cells and mediates AIDS lentivirus-induced $\mathrm{T}$ cell immunodeficiency. AIDS research and human retroviruses. 2013; 29(4):641-651.

102. Miller MM, Petty CS, Tompkins MB and Fogle JE. $\mathrm{CD} 4+\mathrm{CD} 25+\mathrm{T}$ regulatory cells activated during feline immunodeficiency virus infection convert $\mathrm{T}$ helper cells into functional suppressors through a membrane-bound TGFbeta / GARP-mediated mechanism. Virology journal. 2014; $11: 7$.

103. Cuende J, Lienart S, Dedobbeleer O, van der Woning B, De Boeck G, Stockis J, Huygens C, Colau D, Somja J, Delvenne P, Hannon M, Baron F, Dumoutier L, Renauld JC, De Haard H, Saunders M, et al. Monoclonal antibodies against GARP/TGF-betal complexes inhibit the immunosuppressive activity of human regulatory $\mathrm{T}$ cells in vivo. Science translational medicine. 2015; 7(284):284ra256.

104. Liu Y, Zhang P, Li J, Kulkarni AB, Perruche S and Chen W. A critical function for TGF-beta signaling in the development of natural CD4+CD25+Foxp3+ regulatory T cells. Nature immunology. 2008; 9(6):632-640.

105. Stockis J, Fink W, Francois V, Connerotte T, de Smet C, Knoops L, van der Bruggen P, Boon T, Coulie PG and Lucas S. Comparison of stable human Treg and Th clones by transcriptional profiling. European journal of immunology. 2009; 39(3):869-882.
106. Lu L, Wang J, Zhang F, Chai Y, Brand D, Wang X, Horwitz DA, Shi $\mathrm{W}$ and Zheng SG. Role of SMAD and non-SMAD signals in the development of Th17 and regulatory T cells. Journal of immunology. 2010; 184(8):4295-4306.

107. Tone Y, Furuuchi K, Kojima Y, Tykocinski ML, Greene MI and Tone M. Smad3 and NFAT cooperate to induce Foxp3 expression through its enhancer. Nature immunology. 2008; 9(2):194-202.

108. Schlenner SM, Weigmann B, Ruan Q, Chen Y and von Boehmer H. Smad3 binding to the foxp3 enhancer is dispensable for the development of regulatory $\mathrm{T}$ cells with the exception of the gut. The Journal of experimental medicine. 2012; 209(9):1529-1535.

109. Ouyang W, Beckett O, Ma Q and Li MO. Transforming growth factor-beta signaling curbs thymic negative selection promoting regulatory $\mathrm{T}$ cell development. Immunity. 2010; 32(5):642-653.

110. Pastille E, Bardini K, Fleissner D, Adamczyk A, Frede A, Wadwa M, von Smolinski D, Kasper S, Sparwasser T, Gruber AD, Schuler M, Sakaguchi S, Roers A, Muller W, Hansen W, Buer J, et al. Transient ablation of regulatory $\mathrm{T}$ cells improves antitumor immunity in colitis-associated colon cancer. Cancer research. 2014; 74(16):4258-4269.

111. Schuler PJ, Harasymczuk M, Schilling B, Saze Z, Strauss L, Lang S, Johnson JT and Whiteside TL. Effects of adjuvant chemoradiotherapy on the frequency and function of regulatory $\mathrm{T}$ cells in patients with head and neck cancer. Clinical cancer research. 2013; 19(23):6585-6596.

112. Kalathil S, Lugade AA, Miller A, Iyer R and Thanavala Y. Higher frequencies of GARP $(+)$ CTLA-4 $(+)$ Foxp3(+) $\mathrm{T}$ regulatory cells and myeloid-derived suppressor cells in hepatocellular carcinoma patients are associated with impaired T-cell functionality. Cancer research. 2013; 73(8):2435-2444.

113. Laurent C, Muller S, Do C, Al-Saati T, Allart S, Larocca LM, Hohaus S, Duchez S, Quillet-Mary A, Laurent G, Brousset $\mathrm{P}$ and Valitutti S. Distribution, function, and prognostic value of cytotoxic T lymphocytes in follicular lymphoma: a 3-D tissue-imaging study. Blood. 2011; 118(20):5371-5379. 